\title{
Cholecystokinin in the control of gastric acid secretion in man
}

\author{
J W Konturek, R Stoll, S J Konturek, W Domschke
}

\begin{abstract}
This study was designed to determine the role of cholecystokinin in the control gastric acid secretion in men using loxiglumide, a specific cholecystokinin receptor blocker. Three groups of healthy subjects $(\mathbf{A}, \mathbf{B}$, and $\mathbf{C})$ were used; group $A$ - for studies with postprandial gastric secretion, group B - for studies with exogenous gastric secretagogues and group $\mathrm{C}$ for 12 hour intragastric pH-metry. Cephalic phase stimulated by modified sham feeding in group A subjects increased gastric acid secretion to about $50 \%$ of pentagastrin maximum and the treatment with loxiglumide in a standard dose $(20 \mu \mathrm{mol} / \mathrm{kg}$ iv loading dose plus infusion of $20 \mu \mathrm{mol} / \mathrm{kg} / \mathrm{h}$ afterwards) failed to affect this secretion. Gastric acid response to a $5 \%$ peptone meal instilled intragastrically greatly enhanced gastric acid secretion and plasma gastrin concentration but the addition of loxiglumide in the standard dose resulted in further increase in both gastric acid and plasma gastrin responses to peptone meal. Infusion of caerulein in gradually increasing doses (15-120 $\mathrm{pmol} / \mathrm{kg} / \mathrm{h}$ ) and gastrin releasing peptide $(25-200 \mathrm{pmol} / \mathrm{kg} / \mathrm{h})$ resulted in a dose dependent stimulation of gastric acid secretion reaching about $35 \%$ and $25 \%$ of maximum attained with pentagastrin. When loxiglumide was added in a standard dose, the acid responses to caerulein and gastrin releasing peptide were further increased two to three fold attaining the peak reaching, respectively, about $100 \%$ and $50 \%$ of pentagastrin maximum. In group $\mathrm{C}$ subjects, 12 hour pH-metry revealed the usual increase in gastric $\mathrm{pH}$ after each meal in tests with placebo. Loxiglumide (1200 mg tablets tid, po) resulted in significantly lower $\mathrm{pH}$ after each meal and this was accompanied by significantly higher gastrin responses than in placebo tests. We conclude that cholecystokinin released by peptone meal, ordinary meals or gastrin releasing peptide exerts a potent inhibitory influence on gastric acid secretion and gastrin release in men and this inhibition involves subtype $A$ cholecystokinin receptors.

(Gut 1993; 34: 321-328)
\end{abstract}

University Medical

School, Krakow, Poland, and

Department of Medicine, University of Munster, Munster, Germany

J W Konturek

$\mathrm{R}$ Stoll

S J Konturek

W Domschke

Correspondence to:

Prof Dr S J Konturek,

Institute of Physiology,

Grzegorzecka 16, Poland.
Gral

Accepted for publication 14 July 1992

Gastric acid secretion depends upon the interplay of many stimulatory and inhibitory influences that arise within the central nervous system and the gastrointestinal tract resulting in the cephalic, gastric, and intestinal phases of this secretion. ${ }^{\prime}$

Cholecystokinin is one of major gut hormones ${ }^{2}$ that has also been implicated in the control of gastric secretion. Exogenous cholecystokinin or its natural analogue, caerulein, administered alone in fasted humans or in dogs $\mathrm{s}^{3-5}$ caused partial stimulation of gastric acid secretion but when combined with gastrin it inhibited gastrin induced secretion. The inhibitory action of cholecystokinin could not be, however, confirmed on the isolated canine parietal cells which respond to gastrin and cholecystokinin with equal stimulation of acid production. ${ }^{6}$ This discrepancy between the in vivo inhibition and in vitro stimulation by cholecystokinin of acid secretion has been explained that cholecystokinin in vivo may release a local inhibitor of parietal cells such as somatostatin. ${ }^{78}$ Indeed, using a highly selective and potent cholecystokinin receptor blocker such as L-364,718, it was recently found in $\operatorname{dog} s^{910}$ that cholecystokinin released by a protein or fat meal exerts a tonic inhibitory influence on gastric acid secretion and this effect may be mediated, at least in part, by somatostatin. ${ }^{10}$

This study was designed to use the selective antagonist of type A cholecystokinin receptors, loxiglumide, ${ }^{11}{ }^{12}$ to evaluate the role of cholecystokinin in the control of gastric secretion and gastrin release in man under physiological conditions such as cephalic or gastrointestinal phase of this secretion as well as following stimulation with exogenous secretagogues including pentagastrin, caerulein or gastrin releasing peptide.

\section{Methods}

\section{SUBJECTS}

Studies were carried out on three groups $(A, B$, and $\mathrm{C}$ ) of young healthy men (mean age 22 years, range 19-37; mean weight $71 \mathrm{~kg}$, range 59-76). Group A subjects underwent modified sham feeding and peptone meal tests with or without administration of loxiglumide. Group B subjects were used in tests with the infusion of pentagastrin, caerulein or gastrin releasing peptide with or without addition of loxiglumide. Group C subjects were used for the intragastric recording of $\mathrm{pH}$ during 12 hours of normal activities with or without oral administration of loxiglumide. This study was approved by the Human Research Review Committee and informed consent was obtained from each subject.
STUDIES ON THE EFFECTS OF LOXIGLUMIDE ON MODIFIED SHAM FEEDING AND PEPTONE MEAL INDUCED GASTRIC SECRETION

In group A (eight subjects), modified sham feeding and intragastric peptone meal were used to induce, respectively, cephalic vagal and gastrointestinal phases of gastric secretion as described before. ${ }^{13+}$ Briefly, for modified sham feeding, a double lumen Dreiling tube was 

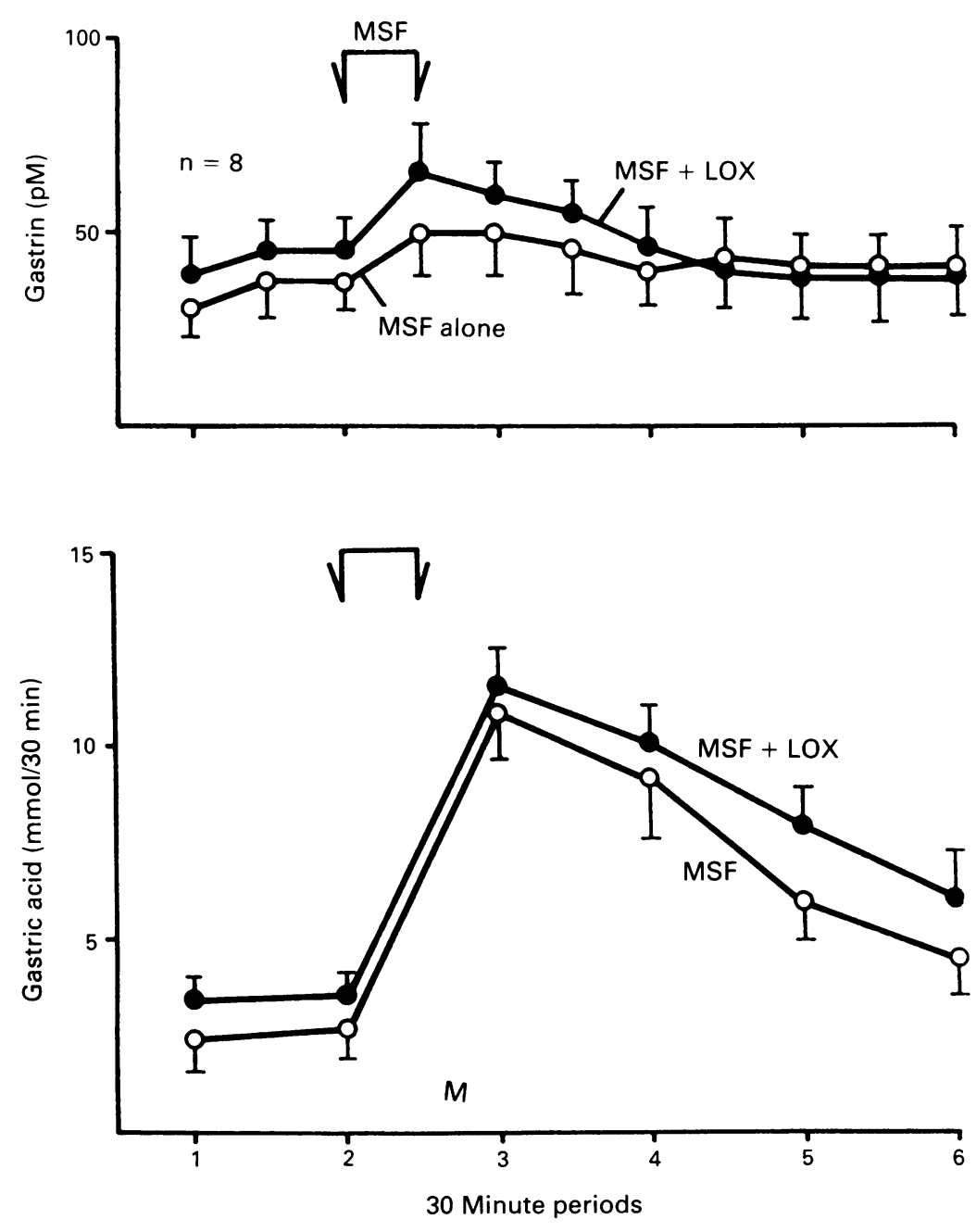

Figure 1: Plasma gastrin concentrations and gastric acid outputs under basal conditions and after modified sham feeding in group $A$ subjects with or without administration of loxiglumide. Mean (SEM) of eight tests on eight subjects.

passed under fluoroscopic control for the aspiration of gastric juice as described previously. ${ }^{1+}$ Residual gastric contents were discarded and the gastric aspirates were collected by a suction pump in 15 minute periods. After 45 minutes basal period, the subjects were served an appetising meal of $250 \mathrm{~g}$ beef steak, $150 \mathrm{~g}$ french potatoes, with about $250 \mathrm{ml}$ water to drink the food was tested, chewed and spat out for 15 minutes. The aspiration of gastric juice was carried out during modified sham feeding and during consecutive 105 minute period. Then pentagastrin $(2 \mathrm{nmol} / \mathrm{kg} / \mathrm{h})$ was infused for 60 minutes and the aspiration of gastric juice was continued to determine maximal acid output in these subjects. All meals were prepared in a separate room so that subjects could not see or smell the food until the time of modified sham feeding and each subject was trained in a preliminary study not to swallow food during chewing. In different test day the modified sham feeding was performed while loxiglumide (kindly provided by Dr L Rovati, Rotta Labs, Milano, Italy) was infused intravenously starting with a loading dose of $20 \mu \mathrm{mol} / \mathrm{kg}$ given during five minutes at the beginning of the test followed by a constant iv dose of $20 \mu \mathrm{mol} / \mathrm{kg} / \mathrm{h}$ throughout the study period.

Six subjects of group A were then used for intragastric peptone meal test (to mimic the gastrointestinal phase of gastric secretion) performed alone or in combination with loxiglumide. On the first test day, 5\% peptone solution (Bactoprotone, Difco Labs, Detroit, Michigan, USA) adjusted to $\mathrm{pH} 5 \cdot 5$ (with $1 \mathrm{M} \mathrm{NaOH}$ ) and osmolarity of about $300 \mathrm{mOsm} / \mathrm{l}$ (with $1 \mathrm{M} \mathrm{NaCl}$ ) was administered during six consecutive 30 minute meals. On a second test day, loxiglumide was administered iv in a loading dose of $20 \mu \mathrm{mol} /$ $\mathrm{kg}$ followed by a constant dose of $20 \mu \mathrm{mol} / \mathrm{kg} / \mathrm{h}$ starting with the fourth 30 minute peptone meal. All tests with peptone meal started after an overnight fast. A double lumen tube was introduced into the stomach and basal gastric acid secretion was quantified by suction aspiration for a 30 minute period. Peptone meal was introduced into the stomach in the volume of $300 \mathrm{ml}$ at the start of each of six consecutive 30 minute periods. The stomach was emptied completely before the administration of the next $300 \mathrm{ml}$ meal. Gastric content was continuously mixed with the aspiration perfusion system and the meal stimulated acid secretion was measured by intragastric titration with the end point of $\mathrm{pH} 5.5$ using $50 \mathrm{mM}$ $\mathrm{Na}(\mathrm{OH})$ as described previously. ${ }^{1+15}$

STUDIES ON THE EFFECTS OF LOXIGLUMIDE ON CAERULEIN, PENTAGASTRIN AND GASTRIN RELEASING PEPTIDE INDUCED GASTRIC SECRETION Group B subjects were also intubated with a double lumen Dreiling tube and gastric acid secretion was stimulated using caerulein (Farmitalia, Milano, Italy) infused iv in gradually increasing doses $(15-120 \mathrm{pmol} / \mathrm{kg} / \mathrm{h})$, each dose being infused for 30 minutes and then doubled with or without addition of loxiglumide (20 $\mu \mathrm{mol} / \mathrm{kg}$ in a loading dose at the start of the study followed by $20 \mu \mathrm{mol} / \mathrm{kg} / \mathrm{h}$ ) given throughout the periods of caerulein administration. After withdrawal of infusion of caerulein, the gastric aspiration was continued for 60 minutes and then pentagastrin $(2.6 \mathrm{nmol} / \mathrm{kg} / \mathrm{h})$ was infused for 60 minutes with or without administration of loxiglumide $(20 \mu \mathrm{mol} / \mathrm{kg} / \mathrm{h})$ to achieve maximal secretory response to this peptide. In six group B subjects, pentagastrin was also infused in separate test day in a constant dose $(0.65 \mu \mathrm{mol} / \mathrm{kg} / \mathrm{h})$ to elicit submaximal secretory response. When gastric acid output in response to pentagastrin reached a well sustained plateau, caerulein was added to iv infusion in a constant dose of 30 $\mathrm{pmol} / \mathrm{kg} / \mathrm{h}$ with or without addition of loxiglumide $(20 \mu \mathrm{mol} / \mathrm{kg} / \mathrm{h})$. In control tests, pentagastrin alone was administered for the entire 150 minutes.

The same six subjects of group B were also used in different occasions in tests with iv infusion of gradually increasing doses (25-200 $\mathrm{pmol} / \mathrm{kg} / \mathrm{h}$ ) of gastrin releasing peptide (gift of Professor N Yanaihara, Shizuoka, Japan) with or without the administration of loxiglumide in a standard dose as used in the feeding experiments.

\section{STUDIES ON THE EFFECT OF LOXIGLUMIDE ON} 12 HOUR INTRAGASTRIC $\mathrm{pH}$

Subjects of group C (eight men) underwent two 12 hour recording tests in a placebo controlled randomised crossover study. Each subject was 

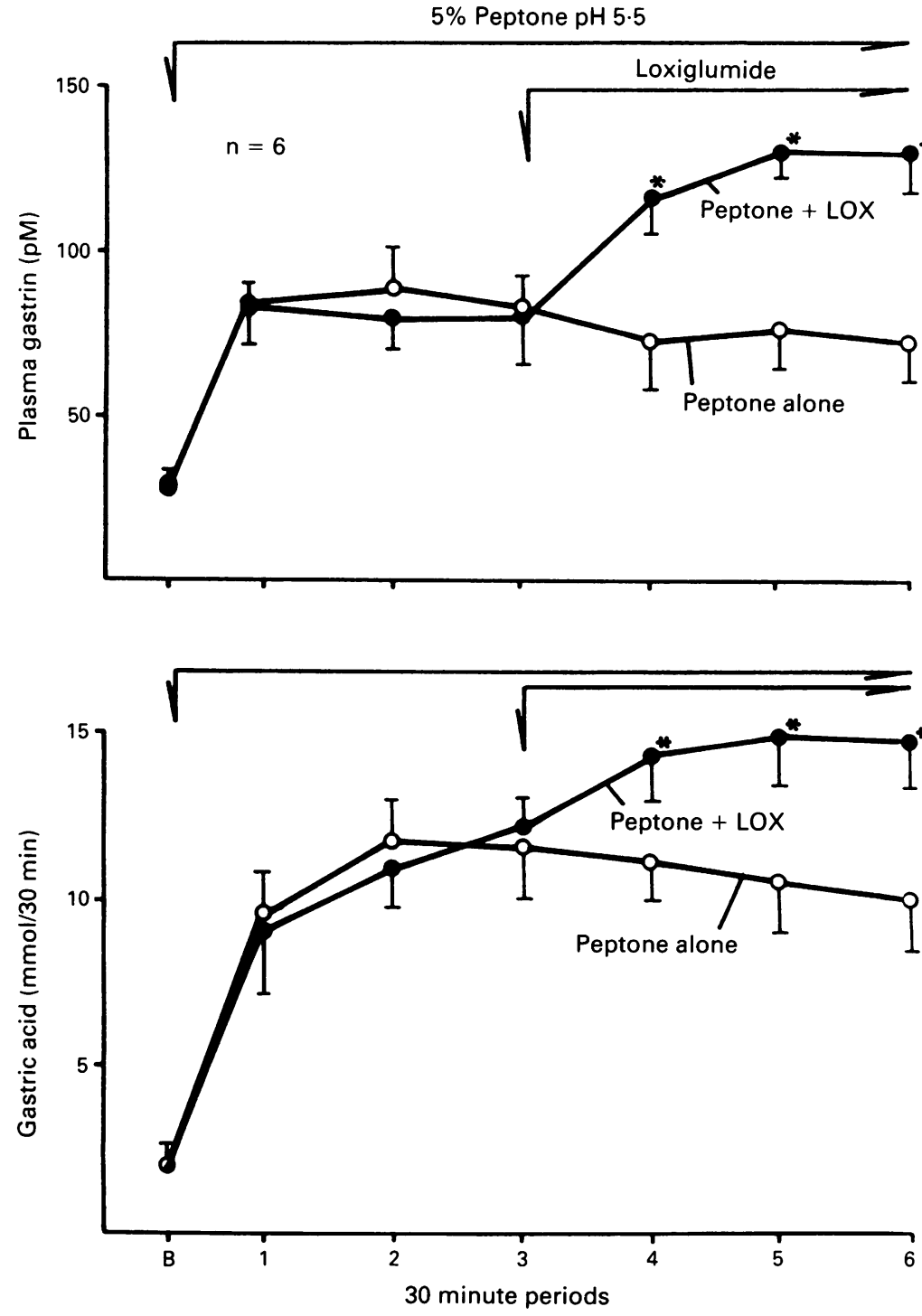

Figure 2: Plasma gastrin and gastric acid responses to intragastric peptone meal without or with iv administration of loxiglumide. Mean of six tests on B subjects. Asterisk indicates significant increase above the control value obtained with peptone meal alone.

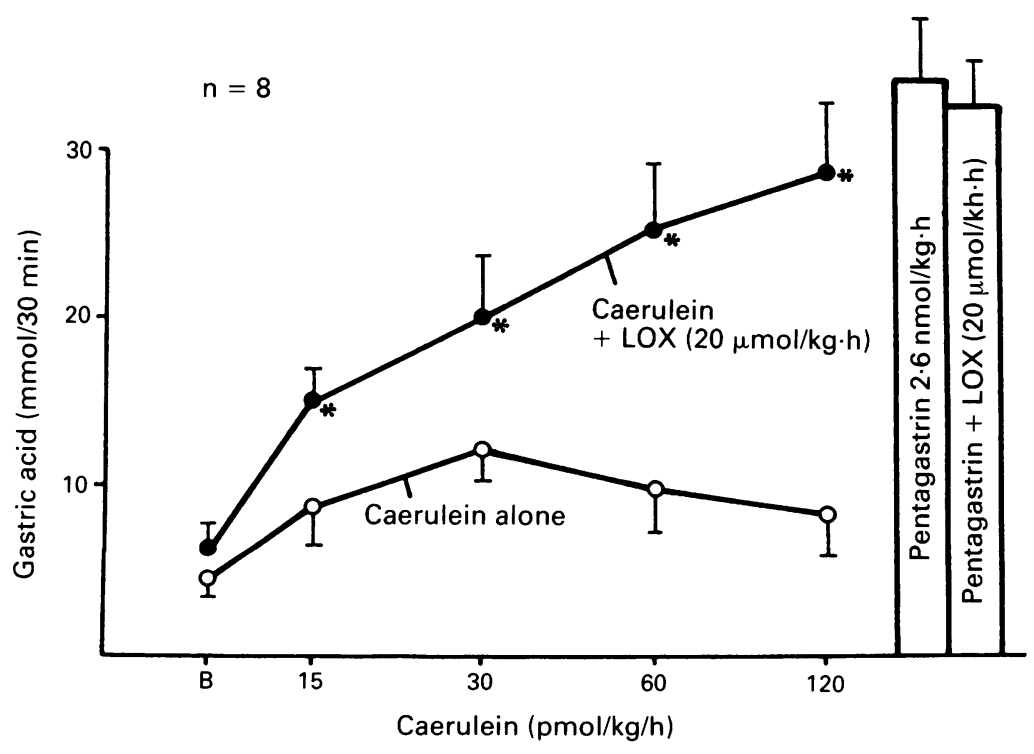

Figure 3: Gastric acid outputs in response to gradually increasing of doses of caerulein alone (15-120 pmol/kg/h) or caerulein combined with a constant background dose of loxiglumide. For comparison maximal gastric acid response to pentagastrin alone $(2.6 \mathrm{nmol} / \mathrm{kg} / \mathrm{h})$ and pentagastrin combined with loxiglumide is in these subjects also presented. Mean (SEM) of eight tests on eight subjects of group $B$. given either placebo or loxiglumide $(1200 \mathrm{mg})$ three times daily 30 minutes before standard liquid meals (Fresubin, Frezenius, Munster, Germany) taken at fixed times: breakfast at 0830 hours, lunch at 1330 hours and supper at 1800 hours. The composition (protein, 3.8\%; amino acids, $0.6 \%$; fat, $3.4 \%$; carbohydrates, $14 \%$; minerals, vitamins and water $84 \%$ ) of each meal was similar and contained about $1 \mathrm{kcal} / \mathrm{ml}$. The volume of breakfast and supper meal was $300 \mathrm{ml}$ and that of lunch meal was $500 \mathrm{ml}$. Recording of intragastric $\mathrm{pH}$ was assessed during 12 hours starting early morning (prebreakfast) by means of an intraluminal system, including an antimony electrode (Monocrystal model 91-0215, Synectics $A B$, Sweden) connected to the portable apparatus, which permitted the $\mathrm{pH}$ recording to be sampled every four seconds (Digitrapper MKII, 6200, Synectics AB, Sweden). The antimony electrode used an external reference on thorax with contact jelly (Hellige 217, Fritze Hellige, FRG). At the beginning and at the end of each examination the antimony electrodes were accurately calibrated at $21^{\circ} \mathrm{C}$ with $\mathrm{pH} 7 \cdot 01$ and pH 1.07 (buffers 5001 and 5002, Synectics $\mathrm{AB}$, Sweden) and a temperature correction for intragastric reading $\left(37^{\circ} \mathrm{C}\right)$ was performed. The $\mathrm{pH}$ electrodes were passed through an anaesthetised nostril and were positioned in the gastric corpus under fluoroscopic control approximately $5 \mathrm{~cm}$ below the lower oesophageal sphincter. The connecting wires were fixed to the nares with adhesive tape. The data recorder of intragastric minielectrodes was carried in a small bag so that it did not interfere with normal daily life. The $\mathrm{pH}$ recordings started at 0810 and lasted for 12 hours. Patients were instructed not to lie down during the day or to take additional meals or alcoholic drinks and carbonated beverages during the examination period.

The data of intragastric $\mathrm{pH}$ monitoring were transferred to IMB compatible computer (PC AT12) programmed with Gastrogram version 5.50 serial No E1024 (Gastrosoft Inc, Sweden) for calculating median $\mathrm{pH}$ values for each 12 hour test. Data from all eight subjects treated with placebo and loxiglumide were analysed with the use of program STAT pHAC II/PHARM, version 2.16 D3 (Gastrosoft Inc, Sweden). Gastric acidity was expressed as $\mathrm{pH}$ and values from each subject were transferred into 10 minute median values. The median and mean 12 hour intragastric $\mathrm{pHs}$ were predefined for comparison between study days using the Wilcoxon's signed rank test. Box whisker plots of median and mean intragastric $\mathrm{pH}$ in eight subjects were performed for 12 hour period and separately for the 120 minute period after each standard meal. Statistics of $\mathrm{pH}$ profile were calculated and compared in medians and means with significance level of less than $0 \cdot 05$.

\section{RADIOIMMUNOASSAY}

Venous blood samples were obtained from peripheral vein under basal conditions and at 30 minute intervals in tests with modified sham feeding, peptone meal, and gastrin releasing peptide infusion. In tests with $12 \mathrm{~h} \mathrm{pH}$-metry, the blood samples were taken 30 and 60 minutes 


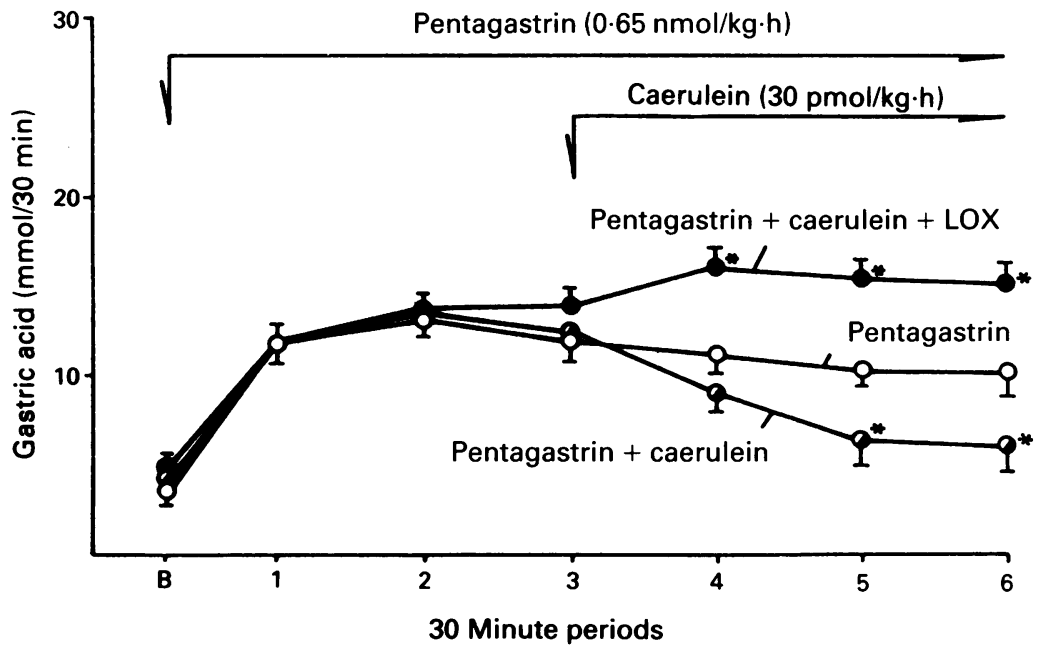

Figure 4: Gastric acid response to pentagastrin infused iv in a dose $(0.65 \mathrm{nmol} / \mathrm{kg} / \mathrm{h})$ producing submaximal stimulation of gastric acid secretion in tests with or without addition of caerulein alone (30 pmol/kg/h) or combined with loxiglumide. Means (SEM) of six tests on six subjects of group $B$. Asterisk indicates significant change as compared with the control value obtained with pentagastrin alone without caerulein or loxiglumide.
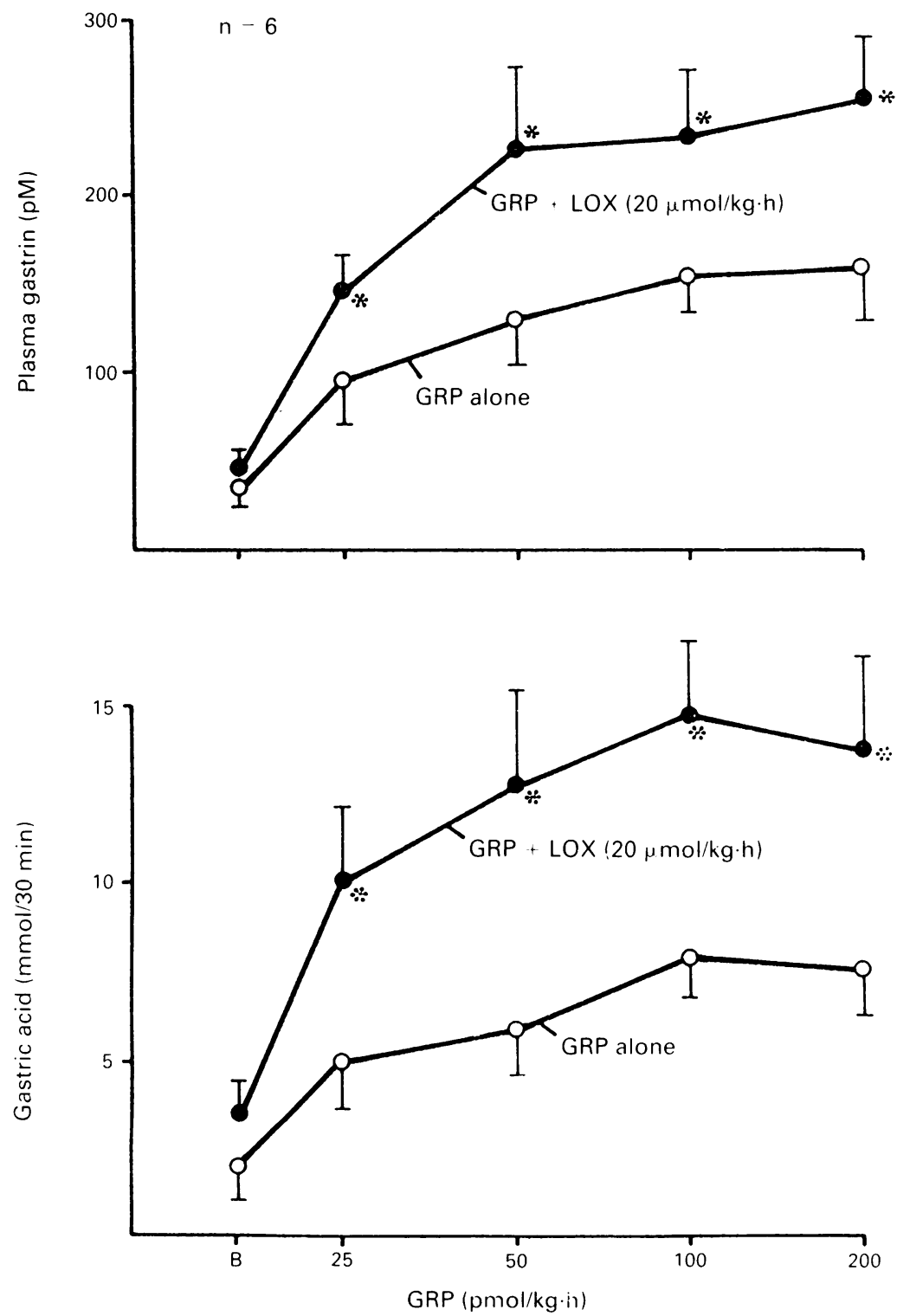

Figure 5: Plasma gastrin and gastric acid responses to graded doses of gastrin releasing peptide (25-200 pmol/kg/h) in six subjects of group B. Mean (SEM) of six tests on six subjects. Asterisk indicates significant increase above the values obtained with gastrin releasing peptide alone. before and 30, 60, and 90 minutes after each meal. Plasma gastrin was determined using gastrin antiserum 4562 kindly donated by Professor $\mathrm{J}$ F Rehfeld of Aarhus, Denmark, and used in a final dilution of 1:140000. Each sample was assayed in duplicate. The sensitivity of the gastrin measurement in the present assay was $2 \cdot 5$ $\mathrm{pmol} / \mathrm{ml}$ serum equivalent to human $\mathrm{G}-17$ as described previously. ${ }^{13}$

\section{STATISTICAL ANALYSIS}

Results are expressed as means (SEM). Statistical significance was determined by both the Wilcoxon's signed-rank test and the paired $t$ test. Significance was accepted with $p$ value less than 0.05 .

\section{Results}

Figure 1 shows gastric acid response to modified sham feeding in group A subjects with or without infusion of loxiglumide. The mean acid output reached peak in the first 30 minute period after the start of modified sham feeding reaching about $50 \%$ of pentagastrin induced maximal acid output (about 26.4 (2.8) $\mathrm{mmol} / 15$ minutes) in these subjects and then declined towards the basal value within consecutive three 30 minute periods of examination. In tests with iv infusion of loxiglumide both basal and modified sham feeding induced peak acid outputs tended to increase above the control values but this increase was not statistically significant. Mean plasma gastrin concentrations also tended to increase after modified sham feeding, particularly in tests with loxiglumide but, again, this rise over premodified sham feeding values did not reach statistical significance.

Intragastric administration of $5 \%$ peptone caused several fold increase in gastric acid secretion over basal value and after 60 minutes acid secretion reached a well sustained plateau throughout the consecutive 30 minute periods (Fig 2). Loxiglumide added to iv infusion resulted in a significant augmentation of acid response to peptone meal and this increase averaged about $30 \%$ of the control value obtained with peptone meal alone. Plasma gastrin rose from basal value of about $25 \mathrm{pmol} / \mathrm{l}$ to the plateau of about $80 \mathrm{pmol} / \mathrm{l}$ after peptone meal and this was further significantly increased when loxiglumide was added to iv infusion.

Caerulein infused iv in gradually increasing doses ranging from 15 to $120 \mathrm{pmol} / \mathrm{kg} / \mathrm{h}$ resulted in a small but significant stimulation of gastric acid secretion reaching peak at a dose of $30 \mathrm{pmol} /$ $\mathrm{kg} / \mathrm{h}$ and amounting to about $35 \%$ of pentagastrin induced maximal acid outputs in these subjects (Fig 3). At a dose of 60 and $120 \mathrm{pmol} / \mathrm{kg} / \mathrm{h}$, acid outputs tended to decline but remained significantly higher than basal acid secretion. When infusion of caerulein was combined with a constant background dose of loxiglumide, gastric acid outputs were significantly higher at all doses of caerulein. The maximal acid response to caerulein combined with loxiglumide was attained at a dose of $120 \mathrm{pmol} / \mathrm{kg} / \mathrm{h}$ and it was not significantly different from that induced with pentagastrin in these subjects. For comparison, 


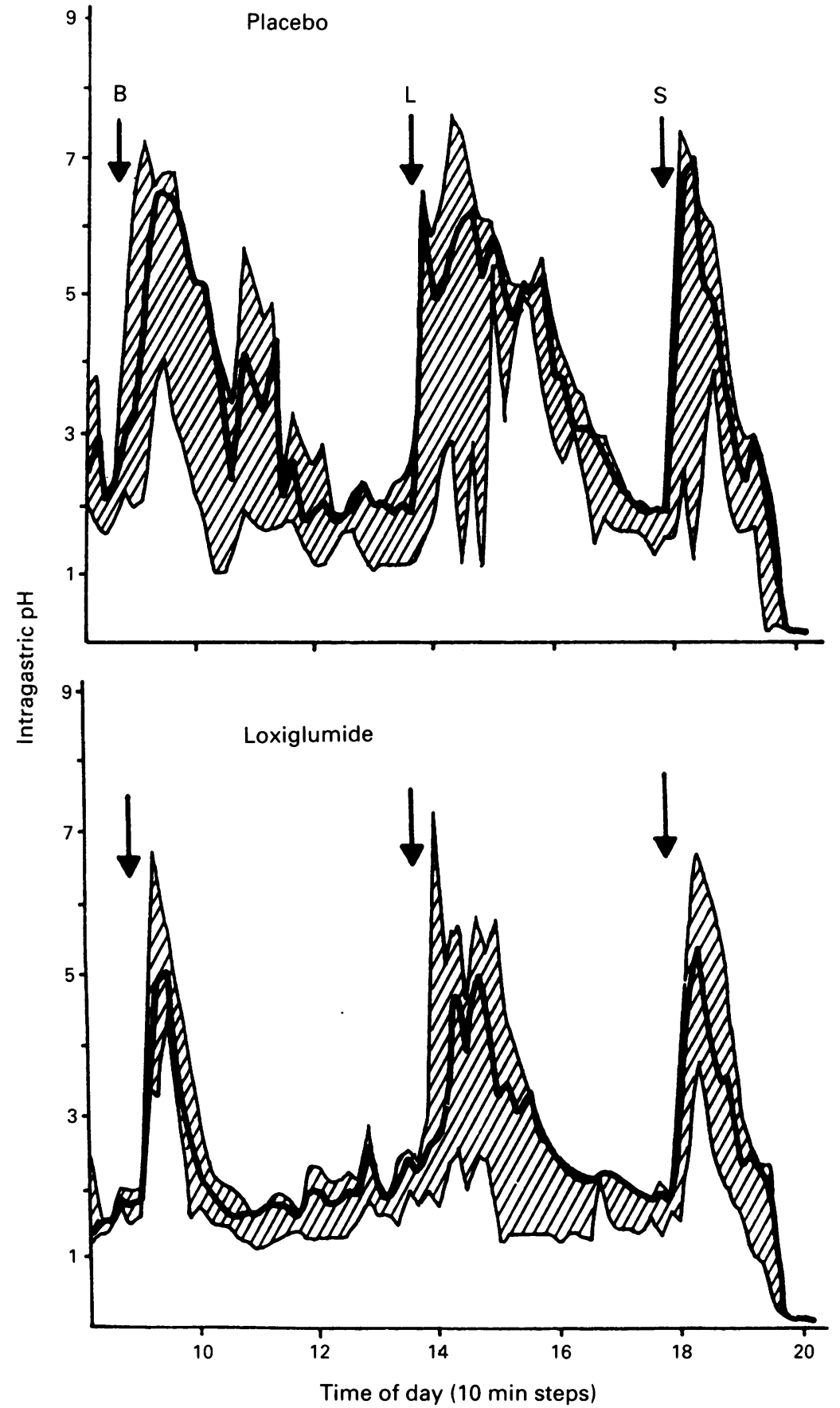

Figure 6: Median intragastric $\mathrm{pH}$ in subjects treated with placebo (upper panel) and loxiglumide (lower panel). Medians of eight tests on eight subjects. The shaded area represents the range of $\mathrm{pH}$ monitoring. of a standard dose of loxiglumide augmented acid outputs at all doses of gastrin releasing peptide and the maximal response to gastrin releasing peptide was achieved at a dose of $100 \mathrm{pmol} / \mathrm{kg} / \mathrm{h}$ reaching about $50 \%$ of pentagastrin maximum.

Gastrin releasing peptide infusion caused a dose dependent increment in plasma gastrin concentrations and the peak gastrin response to gastrin releasing peptide alone was achieved at a dose of $200 \mathrm{pmol} / \mathrm{kg} / \mathrm{h}$. Addition of loxiglumide caused further significant increase in plasma gastrin concentrations at all dose levels of gastrin releasing peptide reaching peak at a dose of 50 $\mathrm{pmol} / \mathrm{kg} / \mathrm{h}$ (Fig 5).

Figures 6 and 7 show the median daytime $\mathrm{pH}$ profile in the same eight subjects treated with placebo or with loxiglumide (1200 mg tid po). For most of the time, the $\mathrm{pH}$ was between 1 and 2 during the interdigestive periods and the median $\mathrm{pH}$ was not significantly different between placebo and loxiglumide treatments. With meals, the $\mathrm{pH}$ rose to $4-6$ and this rise lasted for about 90-180 minutes in subjects treated with placebo. In subjects ingesting loxiglumide, however, the rise in $\mathrm{pH}$ after each of the standard meals was significantly smaller and lasted only about 60-90 minutes. The median and mean postprandial $\mathrm{pH}$ values (for a two hour period after the meal) were significantly lower in tests with loxiglumide as compared with placebo treatments (Fig 8). Plasma gastrin levels between meals in placebo-treated subjects were similar to those in loxiglumide treated subjects but the postprandial increments in plasma gastrin with loxiglumide were significantly higher than in placebo controls (Table).

\section{Discussion}

This study provides evidence that cholecystokinin exerts a tonic inhibitory action on gastric acid secretion and gastrin release in response to ordinary meals, gastric peptone or gastrin releasing peptide in man and that these effects are mediated by the type A cholecystokinin receptors.

Cephalic phase of gastric secretion elicited in the present study by modified sham feeding is assumed to be mediated by vagal nerves stimulating directly the oxyntic cells and activating the release of gastrin and histamine. ${ }^{16}$ The reports concerning the rise in plasma gastrin after modified sham feeding in man are controversial, confirmed by some investigators ${ }^{1718}$ and questioned by others. ${ }^{1319}$ The present study shows only a small and insignificant increment in plasma hormone concentration after the modified sham feeding. The release of cholecystokinin was observed only in anaesthetised dogs with electrically stimulated vagal nerves ${ }^{20}$ but usual cephalic stimulation in conscious dogs attained by sham feeding or insulin hypoglycaemia failed to result in any significant change in plasma cholecystokinin concentrations. ${ }^{21}$ Our results in man show that the pretreatment with loxiglumide did not affect significantly gastric acid secretion or plasma gastrin response to modified sham feeding indicating that cephalic vagal excitation does not involve cholecystokinin. This is in keeping with the recent finding 


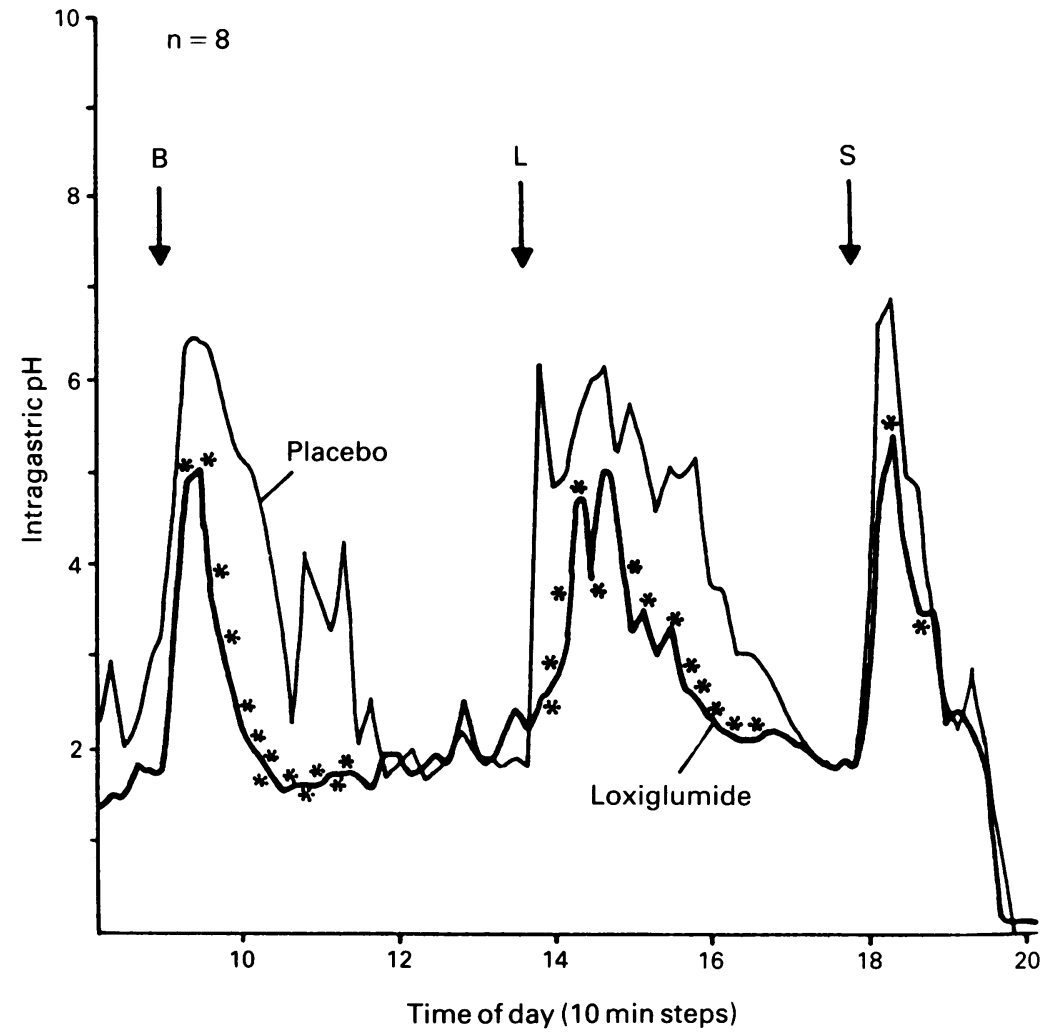

Figure 7: Median intragastric $\mathrm{pH}$ values in tests with placebo and loxiglumide before and after breakfast, lunch, and supper meals. Asterisk indicates significant $(p<0.05)$ change as compared with placebo control.

showing that vagotomy in man did not influence the release of cholecystokinin but only increased the sensitivity of target organs to this hormone. ${ }^{22}$ In this study loxiglumide failed to affect basal gastric acid outputs and plasma gastrin concentrations suggesting that cholecystokinin does not play any role in the control of basal gastric secretion.

The gastrointestinal phase of gastric acid secretion was reproduced in this study by the intragastric instillation of $5 \%$ peptone meal kept at a constant $\mathrm{pH} 5.5$ in the stomach by intragastric titration technique. ${ }^{14}$ is Such a procedure prevented the usual fall in the intragastric $\mathrm{pH}$ after a meal and resulted in a well sustained stimulation

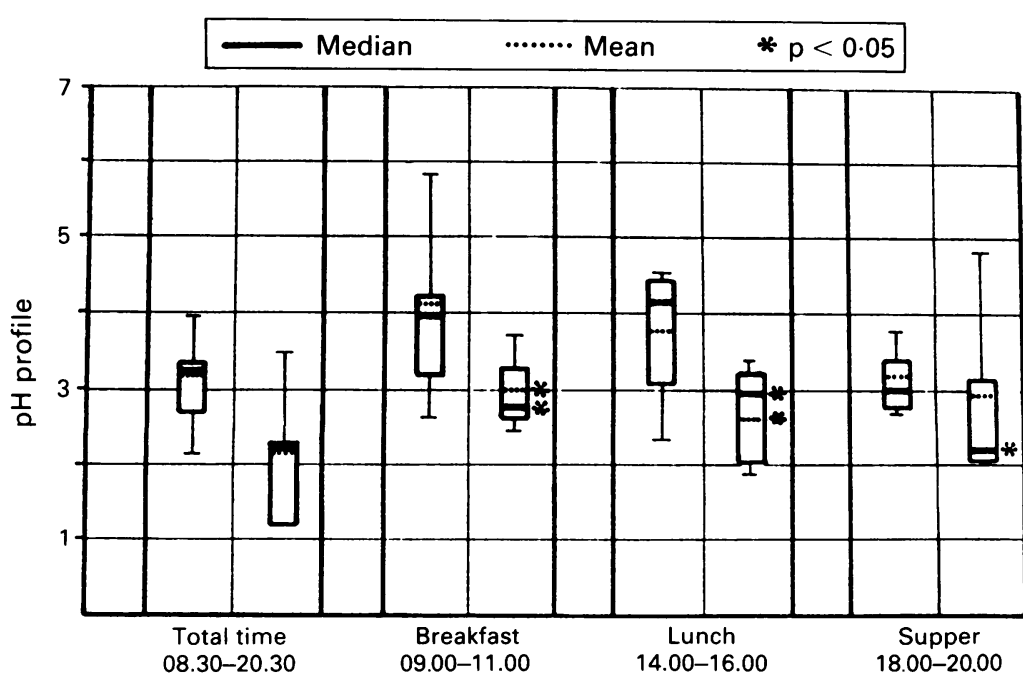

Figure 8: Box-whisker plots of median with interquartile range and mean postprandial $\mathrm{pH}$ in eight subjects as determined for two hours after ingestion of standard meal. Asterisk indicates significant $(p<0.05)$ difference as compared with placebo control. of gastric acid secretion reaching about $50 \%$ of pentagastrin maximum in these subjects. It was accompanied by several fold increase in plasma gastrin concentrations probably reflecting an excessive release of antral hormone as a result of gastric distention by the meal and the action of peptic digests at high $\mathrm{pH}$ on the antral G-cells. ${ }^{1+}$

The question remains whether such artificial gastrointestinal meal composed of protein digests stimulates the release of cholecystokinin in man and whether the amounts of hormone released are sufficient to affect gastric acid secretion. In our previous study with a similar gastric peptone meal in man, plasma cholecystokinin rose several fold over basal value and exogenous cholecystokinin in a dose as low as $20 \mathrm{pmol} / \mathrm{kg} / \mathrm{h}$ caused significant inhibition of gastric acid secretion in response to this meal. As the pretreatment with loxiglumide completely abolished the inhibitory effect of exogenous cholecystokinin on meal induced gastric acid secretion we assumed that cholecystokinin induced gastric acid secretion was mediated by type A cholecystokinin receptors. The gastric acid secretion induced by peptone meal itself, however, was not affected by the loxiglumide in that study probably because of the relatively low dose of loxiglumide $(800 \mathrm{mg}$ po plus iv infusion of $1 \mathrm{mg} / \mathrm{kg} / \mathrm{h}$ ) used. Also the failure of the MK-329, another potent type A cholecystokinin receptor blocker, to affect the peptone meal induced gastric acid secretion in dogs" was probably related to the insufficient dose of the blocker used intragastrically. In the present study we decided to use loxiglumide in larger intravenous dose $(20$ $\mu \mathrm{mol} / \mathrm{kg}$ loading dose plus $20 \mu \mathrm{mol} / \mathrm{kg} / \mathrm{h}$ infused iv afterwards) because our dog experiments revealed that the bioavailability of loxiglumide from the gastrointestinal tract was only about $40 \%{ }^{23}$ and because other reports showed that higher doses of this blocker in humans are safe and well tolerated. ${ }^{2+25}$ Such large dose of loxiglumide applied iv did not influence basal gastric acid secretion or basal plasma gastrin concentration (see Figure 6) but greatly augmented the peptone stimulated gastric acid secretion and significantly raised the postprandial plasma gastrin concentrations indicating that, indeed, cholecystokinin released by this peptone has a tonic inhibitory influence on both gastric acid secretion and gastrin release in man.

Peptone solution applied intragastrically is, however, highly artificial meal because it involves the constant neutralisation of secreted acid by intragastric titration and prevents the usual rise in the intragastric acidity after the meal. Therefore, we also used the most physiological assessment of intragastric acidity by continuous $\mathrm{pH}$-metry using intraluminal $\mathrm{pH}$ electrode that has been recently validated in healthy subjects and peptic ulcer patients ${ }^{2627}$ and used to monitor the action of various drugs on gastric acid secretion. ${ }^{2 x}$ Loxiglumide given orally three times daily before each meal did not influence the interdigestive $\mathrm{pH}$ but resulted in a significantly lower intragastric $\mathrm{pH}$ after each meal indicating an overall increase in the postprandial gastric acid secretion. Yet, despite the enhanced gastric acid secretion and lower intragastric $\mathrm{pH}$, the plasma gastrin response to the 
Plasma gastrin concentrations as determined 60 and 30 minutes before each meal and 30, 60, and 90 minutes after each meal (breakfast, lunch, and supper) during 12 hour pH-metry tests in placebo and loxiglumide treated subjects. Means (SEM) of eight tests on eight subjects

\begin{tabular}{|c|c|c|c|c|c|c|c|c|c|c|}
\hline & \multicolumn{5}{|c|}{$\begin{array}{l}\text { Placebo } \\
\text { Gastrin (pmolll) } \\
\text { Time (min) }\end{array}$} & \multicolumn{5}{|c|}{$\begin{array}{l}\text { Loxiglumide } \\
\text { Gastrin (pmol/l) } \\
\text { Time (min) }\end{array}$} \\
\hline & -60 & -30 & 30 & 60 & 90 & -60 & -30 & 30 & 60 & 90 \\
\hline $\begin{array}{l}\text { Breakfast } \\
\text { Lunch } \\
\text { Supper }\end{array}$ & $\begin{array}{l}22 \cdot 8 \\
(1 \cdot 4) \\
22 \cdot 8 \\
(1.0) \\
23 \cdot 6 \\
(1 \cdot 0)\end{array}$ & $\begin{array}{l}23 \cdot 2 \\
(1 \cdot 6) \\
21 \cdot 2 \\
(1 \cdot 2) \\
22 \cdot 2 \\
(1 \cdot 2)\end{array}$ & $\begin{array}{l}32 \cdot 0^{\star} \\
(2 \cdot 6) \\
27 \cdot 4^{\star} \\
(1 \cdot 8) \\
28 \cdot 4^{\star} \\
(1 \cdot 8)\end{array}$ & $\begin{array}{l}29 \cdot 4^{\star} \\
(1 \cdot 0) \\
29 \cdot 0^{\star} \\
(1 \cdot 6) \\
29 \cdot 2^{\star} \\
(1 \cdot 0)\end{array}$ & $\begin{array}{l}29 \cdot 0^{\star} \\
(1 \cdot 8) \\
31 \cdot 6^{\star} \\
(2 \cdot 8) \\
27 \cdot 2 \\
(1 \cdot 8)\end{array}$ & $\begin{array}{l}23 \cdot 0 \\
(1 \cdot 2) \\
22 \cdot 8 \\
(1 \cdot 8) \\
25 \cdot 0 \\
(1 \cdot 6)\end{array}$ & $\begin{array}{l}21 \cdot 4 \\
(1 \cdot 8) \\
23 \cdot 0 \\
(1 \cdot 6) \\
24 \cdot 8 \\
(1 \cdot 6)\end{array}$ & $\begin{array}{l}42 \cdot 6^{\star} \dagger \\
(2 \cdot 4) \\
48 \cdot 2^{\star} \dagger \\
(4 \cdot 4) \\
45 \cdot 8^{\star} \dagger \\
(4 \cdot 1)\end{array}$ & $\begin{array}{l}38 \cdot 4^{\star} \dagger \\
(2 \cdot 6) \\
47 \cdot 0^{\star} \dagger \\
(2 \cdot 7) \\
46 \cdot 6^{\star} \dagger \\
(2 \cdot 6)\end{array}$ & $\begin{array}{l}33 \cdot 6^{\star} \\
(2 \cdot 8) \\
49 \cdot 2^{\star} \dagger \\
(1 \cdot 9) \\
34 \cdot 8^{\star} \\
(2 \cdot 6)\end{array}$ \\
\hline
\end{tabular}

* Significant change $(\mathrm{p}<0.05)$ as compared with the value before the meal. + Significant change $(\mathrm{p}<0.05)$ as compared with the value obtained in placebo treated subjects.

standard meal in loxiglumide treated subjects reached significantly higher increments than in placebo treated subjects. Thus, the removal of the effects of endogenous cholecystokinin by the antagonism of its type $A$ receptors with loxiglumide resulted in an increase in gastric acid secretion and gastrin release under physiological postprandial conditions.

The mechanism of the action of cholecystokinin on gastric acid secretion observed previously in $\operatorname{dogs}^{910}$ and in the present report in man has not been explained but it appears to be of dual character. One component of this action is a stimulatory effect but it is rather weak and probably involves the B type of cholecystokinin/ gastrin receptors. ${ }^{10}$ This stimulatory component has been well documented under the in vitro conditions when cholecystokinin or its natural analog, caerulein, was found to be equipotent with that of gastrin in the stimulation of acid production. Under in vivo conditions, however, the stimulatory component is rather weak as shown in the present study by a small increase in acid secretion in response to iv infusion of graded doses of caerulein. When caerulein was added to pentagastrin infusion, a significant inhibition of gastric secretion was observed indicating that the predominant component of the action of caerulein is the inhibition of gastrin-stimulated gastric secretion. The antagonism of type A receptors with loxiglumide eliminated the inhibitory component as evidenced in this study by the conversion of caerulein from partial into the full gastrin like agonist of gastric secretion and by the reversal of the inhibitory effect of caerulein on the pentagastrin induced secretion. This effect of loxiglumide was probably mediated by type A cholecystokinin receptors probably localised on the somatostatin producing cells. $^{7-1029}$ The pretreatment with loxiglumide failed to affect the pentagastrin induced gastric acid secretion (see Figure 3 ) indicating that pentagastrin acts predominantly via the type B cholecystokinin/gastrin receptors and that loxiglumide is specific antagonist of the type A but not the type $B$ receptors. Selective antagonism of type B cholecystokinin/gastrin receptors would be necessary to conclude that the stimulatory effect of cholecystokinin or caerulein on gastric acid secretion is caused by the type $B$ receptors. In dogs, such blockade of type B cholecystokinin receptors with selective antagonist $\mathrm{L}-365,260$ completely eliminated the stimulatory effects of gastrin and cholecystokinin on gastric acid secre- tion. ${ }^{29}$ Recent studies in man with the blocker of the type B receptors using L-365,260 revealed that such antagonism inhibited pentagastrin induced gastric acid secretion ${ }^{30}$ but no attempts were made to determine whether cholecystokinin or caerulein induced gastric acid secretion is affected by L-365, 260 .

The postprandial stimulation of gastric secretion and gastrin release can also be mimicked by infusion of gastrin releasing peptide. ${ }^{31}$ It is of interest that despite an excessive gastrin release as evidenced by the pronounced increment in plasma gastrin concentration, gastrin releasing peptide was rather weak stimulant of gastric acid secretion. The highest observed gastric acid response to gastrin releasing peptide reached only about $25 \%$ of pentagastrin maximum and this corresponded to about $60 \%$ of peptone meal induced acid output. After the blockade of the type A cholecystokinin receptors with loxiglumide, both gastric acid outputs and increments in plasma gastrin showed further significant increase. These results could be interpreted that cholecystokinin, that was shown to be released by gastrin releasing peptide, ${ }^{32}$ attenuates the stimulatory action of concurrently released endogenous gastrin on oxyntic glands so only a small increase in gastric acid secretion is observed after administration of gastrin releasing peptide. After the elimination of the inhibitory component of cholecystokinin by the blockade of type A cholecystokinin receptors with loxiglumide, only the stimulatory action of cholecystokinin and gastrin persisted and this was probably mediated entirely by type $B$ cholecystokinin/gastrin receptors at the oxyntic glands.

1 Hirschowitz BI. Neural and hormonal control of gastrin secretion In: Schultz SG ed. The gastrointestinal system. secretion. In: Schultz SG, ed. The gastrointestinal system. Handbook of physiologv. Vol 11.

2 Walsh JH. Gastrointestinal hormones. In: Johnson LR, ed Physiology of the gastrointestinal tract. New York: Raven
Prod Press, 1987: 181-252.

3 Johnson LR, Grossman MI. Analysis of inhibition of acid secretion by cholecystokinin in dogs. Am $\mathcal{F}$ Physiol 1970; 218: $550-4$.

4 Corazziari E, Solomon TE, Grossman MI. Effect of ninety-five percent pure cholecystokinin on gastrin stimulated acid secretion in man and in dog. Gastroenterology 1979; 77: 91-5.

5 Mayer EA, Elashoff J, Mutt V, Walsh JH. Reassessment of gastric acid inhibition by cholecystokinin and gastric inhibitory polypeptide in dogs. Gastroenterolog $v$ 1982; 83: 1047-50.

6 Soll A, Amirian D, Thomas L, Reedy T, Elashoff J. Gastrin receptors on isolated canine parietal cells. $\mathcal{F}$ Clin Invest 1984; 73: 1434-47.

7 Soll A, Amirian D, Park J, Elashoff J, Yamada T. Cholecystokinin potently releases somatostatin from canine fundic mucosal cells in short-term culture. Am J Physiol 1985; 248: G569-73. 
8 Bengtsson $\mathrm{P}$, Lundquist G, Nilson G. Inhibition of acid formation and stimulation of somatostatin release by cholecystokinin-related peptides in rabbit gastric glands. $\mathcal{f}$ Physiol (Lond) 1989; 419: 767-74

9 Lloyd KCK, Maxwell V, Kovacs TOG, Miller J, Walsh JH. Cholecystokinin receptor antagonist MK-329 blocks intestinal fat-induced inhibition of meal-stimulated gastric acid secretion. Gastroenterology 1992; 102: 103-38.

10 Konturek SJ, Tasler J, Cieszkowski M. Role of cholecystokinin in the inhibition of gastric acid secretion in dogs. $\tilde{F}$ Physiol 1992; 451: 477-89.

11 Setnikar I, Christe R, Makovec F, Rovati LC, Warrington SJ Pharmaceokinetics of loxiglumide after single intravenous or Pharmaceokinetics of loxiglumide after single intravenous or
oral doses in man. Arzneim Forsch Drug Res 1988; 38: oral doses

12 Konturek JW, Konturek SJ, Kurek A, Bogdal J, Oleksy J, Rovati LC. CCK receptor antagonism by loxiglumide and gallbladder contractions in response to cholecystokinin, sham-feeding and ordinary feeding in man. Gut 1989; 30: $1136-42$.

13 Konturek SJ, Swierczek J, Kwiecien N, Obtulowicz W, Dobrzanska M, Kopp B, et al. Gastric secretory and plasma hormonal repsonses to sham-feeding of varying duration in patients with duodenal ulcer. Gut 1981; 22: 1003-10.

14 Konturek SJ, Biernat J, Kwiecien N, Oleksy J. Effect of glucagon on meal-induced gastric secretion in man. Gastroenterology 1975; 68: 448-54

15 Konturek SJ, Kwiecien N, Obtulowicz W, Kopp B, Oleksy J, Rovati L. Cholecystokinin in the inhibition of gastric Rovati L. Cholecystokinin in the inhibition of gastric 45: $1-8$.

16 Grossman MI. Regulation of gastric acid secretion. In: Johnson LR, ed. Physiology of the gastrointestinal tract. Vol 1 . New York: Raven Press, 1981: 659-71

17 Richardson CT, Walsh JH, Cooper KA, Feldman M, Fordtran JS. Studies on the role of cephalic-vagal stimulation in the acid response to eating in normal human subjects. $f$ Clin Invest 1977; 60: 435-41.

18 Feldman $M$, Walsh JH. Acid inhibition of sham-feeding stimulated gastrin release and gastric acid secretion: effect of atropine. Gastroenterology 1978; 20: 875-81.

19 Stenquist B, Nilson G, Rehfeld JT, Olbe L. Plasma gastrin concentrations following sham feeding in duodenal ulcer patients. Scand f Gastroenterol 1979; 14: 305-11.

$20 \mathrm{Kim} \mathrm{CK}$, Lee KY, Wang T, Sun G, Chang TM, Chev WY.
Role of endogenous cholecystokinin in vagally stimulated pancreatic secretion in dogs. Am fo Physiol 1989; 257: G944-9.

21 Konturek SJ, Bielanski W, Solomon TE. Effects of an antra mucosectomy, L-364,718 and atropine on cephalic phase of gastric and pancreatic secretion in dogs. Gastroenterolog 1990; 98: 47-55.

22 Masclee AA, Jansen JB, Driessen WM, Geuskens I.M, Lamers CB. Effects of truncal vagotomy on cholecystokinin release, gallbladder contraction, and gallbladder sensitivity to cholecystokinin in humans. Gastroenterology 1990; 98: $1338-44$.

23 Cieszkowski M, Tasler J, Konturek SJ. Comparison of intravenous and intraduodenal loxiglumide on pancreatic secretion in dogs. Digestion (in press)

24 Niederau C, Heintges T, Rovati L, Strohmeyer G. Effects of loxiglumide on gallbladder emptying in healthy volunteers. Gastroenterology 1989; 97: 1331-6.

25 Adler G, Beglinger C, Braun U, Reinshagen M, Kopp I, Schafmayer A, et al. Interaction of cholinergic system and cholecystokinin in the regulation of endogenous and exogenous stimulation of pancreatic secretion in humans. Gastroenterology 1991; 100: 537-43.

26 Merki HS, Fimmel CJ, Walt RP, Harre K, Rohmel J, Witzel $\mathrm{L}$. Pattern of $24 \mathrm{~h}$ intragastric acidity in active duodenal ulcer disease and in healthy controls. Gut 1988; 29: 1583-7.

27 Kauper BK, Bardhan KD. The 24h intragastric $\mathrm{pH}$ profile: changes in healed and unhealed duodenal ulcer disease. Eur changes in healed and unhealed duodenal Hepatol 1990; 2: 258-90.

28 Savarino V. Continuous intragastric $\mathrm{pH}$ monitoring a real progress in the assessment of antisecretory drugs. Ital $\mathfrak{f}$ Gastroenterol 1990; 22 (suppl 2): 10-23.

29 Konturek SJ, Bilski J, Cieszkowski M. Role of cholecystokinin in the intestinal fat- and acid-induced inhibition of gastric secretion. Regul Pept (in press).

30 Sytnik B, Murphy G, Kovacs TOG, Mertz H, Maxwell V, Gertz B, Wals JH. Oral L-365,260 inhibits pentagastrinstimulated acid secretion in man. Gastroenterology 1992, 102: A171

31 Lundell L, Lindstedt G, Olbe L. Origin of gastrin liberated by gastrin releasing peptide in man. Gut 1987; 28: 1128-33.

32 Lundell L, Cantor P, Sjovall M, Rehfeldt JF, Olbe L. Factor influencing the release of cholecystokinin induced by gastrin influencing the release of cholecystokinin induced by gastrin $544-50$. 